\title{
最近の無電解めっき技術
}

\author{
斎 藤囲*
}

*(侏ハイテクノ（テ143-0003＼cjkstart東京都大田区京浜島 2-16)

\section{Recent Trend of Electroless Plating}

Mamoru SAITO*

*Hightechno Co., Ltd. (2-6, Keihinjima, Ota-ku, Tokyo 143-0003)

Key Words : Electroless Nickel, Electroless Copper, Electroless Gold, Electroless Silver

\section{1.はじめに}

無電解めつき技術の最近の動向について概述するのが目的 であるが, はじめに無電解めっき技術の共通の項目について 復習し，進歩の原点を明らかにしておきたい。

今日の工業的な無電解ニッケルめつきや無電解銅めつきが 実用化される以前には, 古くからガラス鏡またはレコード原 盤製造に使用されていた銀鏡反応やアルミニウムのジンケー 卜処理のような電気を使わないめっき方法があって, それぞ れ工業的に重要な役割をはたしていた。これらの古典的技術 を含めて, 外部電源を用いないめっきには無電解めっき, 化 学めつき, 置換めつき(浸漬めつきともよばれる)などのこと ばが用いられている。電気を使わない(水溶液からの)めっき をすべて無電解めっきとよぶことにすれば，それぞれの反応 のしくみによって図 1 のように分類することができる。図 1 で置換めっきの例にあげたジンケート処理とは，アルカリ性 覀鉛酸溶液(ジンケート溶液) 中にアルミニウム素材を浸漬し て两鉛を置換析出させる方法で, 反応は次のように表され る;

$$
2 \mathrm{Al}+3 \mathrm{Zn}^{2+} \rightarrow 2 \mathrm{Al}^{3+}+3 \mathrm{Zn}
$$

表面が酸化しやすいアルミニウム素材上に覀鉛置換膜を被 覆することによって, この上に密着性のよいめつきが可能に なる。この反応の駆動力はアルミニウムと亜鉛の電極電位差, いいかえればイオン化傾向の差である。この場合にはアルミ ニウム素材が還元剤の役割をはたしている。したがって，ア

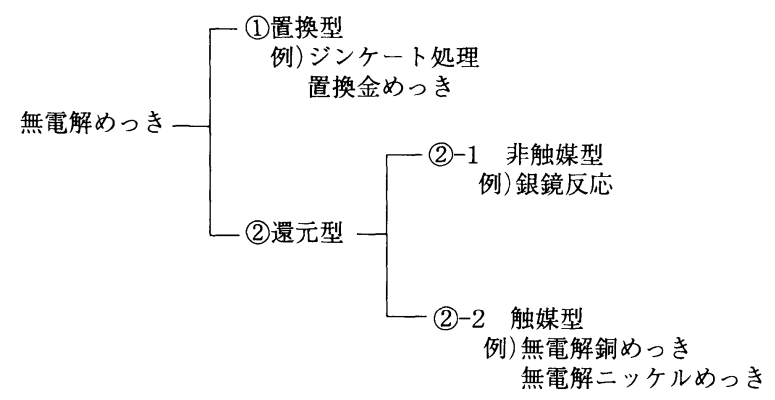

図 1 無電解めつきの反応機構による分類
ルミニウム表面がすべて亜鉛で被覆されると反応は停止する。 後述する自己触媒型の無電解めっきと違って, 置換めっきで は厚いめっきは期待できない。電子回路に使用される置換金 めつきもこの範疇に属する。

図 1 では, 置換型めっきに対して化学還元剤を含む浴を使 用する無電解めっきを還元型として分類している。古くから 知られている銀鏡反応は, 本来ガラス上の銀めっきに使用さ れたものである。この場合，素材は非金属なので(1)のような 置換反応は起こり得ない。したがって銀鏡反応では糖類やホ ルムアルデヒドなどの化学還元剤を使用する。還元型の無電 解めっきは, さらに非触媒型と触媒型に分類され, 銀鏡反応 は前者に属する。銀鏡反応の場合, 銀塩溶液と還元剤を混合 させると, 還元反応は被めっき体表面に限定されずに, 浴中 でも容器壁でも見さかいなく進行する。したがって, めっき 液は一度しか使用できず，めっき膜成長には限界がある。

これに対して次垔りン酸塩を還元剂とする無電解ニッケル めっきやホルムアルデヒドを還元剤とする無電解銅めっきは 自己触媒型に属する。これらの無電解めっきでは, めっきさ れた金属が還元めっき反応の触媒になるので，めつき反応は 被めっき体表面に限定され, 溶液中や容器壁上で起こりにく い。補給によって浴組成を維持するかぎりめっき反応は持続 するので，ほぼ時間に比例した厚いめっきが得られる。電子 回路に使用される無電解金めっきには, 目的に応じて置換型 金めつきと触媒型金めつきがある。このほか最近の研究によ れば, 素材触媒型無電解金めっきとよばれるものもある。こ のタイプでは置換型とは異なり化学還元剤を使用するが, 素 材の被覆が完了すると反応は停止する。

触媒型無電解めっきの反応は混成電位論によって説明する ことができる。ホルムアルデヒドを還元剤とする無電解銅 めっき浴を例に説明する。金属銅または触媒化処理した表面 を浴中に浸漬すると, 間もなく素材表面から水素ガスが発生 しながら反応が開始する。L 錯塩生成のための配位子, 浴 中の銅錯イオンを $\mathrm{Cu}^{2+}-\mathrm{L}$ とすれば, 無電解銅めっきの反応 は次式にしたがう;

$$
\mathrm{Cu}^{2}+-\mathrm{L}+2 \mathrm{HCHO}+4 \mathrm{OH}^{-}
$$

$$
\rightarrow \mathrm{Cu}+\mathrm{H}_{2}+2 \mathrm{HCOO}^{-}+2 \mathrm{H}_{2} \mathrm{O}+\mathrm{L}
$$




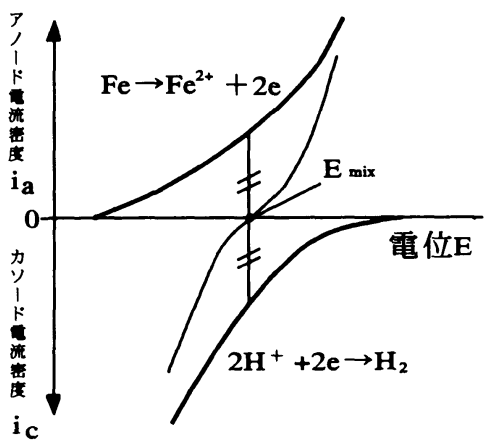

(a)

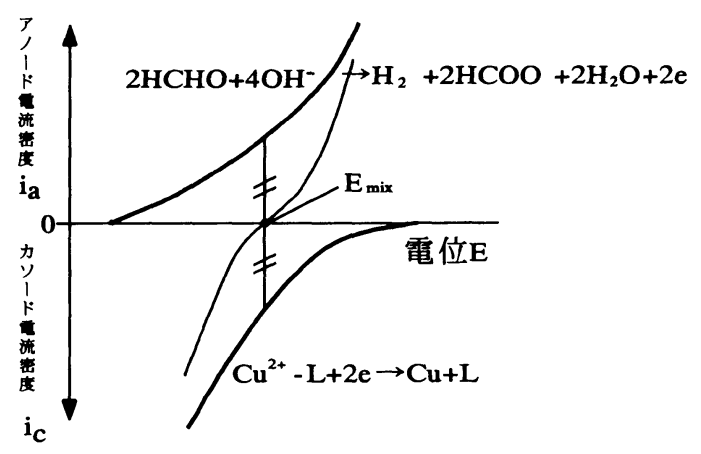

(b)

図 2 酸による鉄の腐食反応 (a) と無電解銅めっき反応 (b) の混成電位 $\mathrm{E}_{\mathrm{mix}}$ の対比 混成電位 $\mathrm{E}_{\mathrm{mix}}$ では, ia = - ic が成立する。

この反応は銅を触媒とする自己触媒反応だから，成分の補 給によって浴組成が維持されるかぎり, 反応は持続する。こ の無電解銅めっきの反応は, 混成電位で起こる局部電池反応 であることが証明されている。最初に斎藤 ${ }^{1}$ が酒石酸塩浴に 関する実験から局部電池モデルとして提案，その後 Paunovic $^{2)}$ がEDTA 浴に展開し, 混成電位論として知られ るようになった。めつき表面の局部カソードでは $\mathrm{Cu}^{2+}$ の力 ソード還元反応が, 局部カソードでは HCHOのアノード酸 化反応が起こる。HCHOのアノード酸化反応は $\mathrm{Cu}$ 上で進 行する触媒反応である。

[局部カソード反応]

$$
\mathrm{Cu}^{2+}-\mathrm{L}+2 \mathrm{e} \rightarrow \mathrm{Cu}+\mathrm{L}
$$

[局部アノード反応]

$$
2 \mathrm{HCHO}+4 \mathrm{OH}^{-} \rightarrow \mathrm{H}_{2}+2 \mathrm{HCOO}^{-}+2 \mathrm{H}_{2} \mathrm{O}+2 \mathrm{e}
$$

混成電位論は，酸性溶液中の鉄の腐食反応と対比すると分 かりやすい。塩酸溶液中に鉄を腐食すると，水素を発生しな がら鉄が溶解する。この腐食反応も局部電池反応であり, 混 成電位(腐食電位)付近の電流一電位曲線は図 2 (a)のように 描くことができる。細線が総合反応の分極曲線(外部分極曲 線), 太線が局部反応の分極曲線である。同様に無電解銅 めっき反応における混成電位(めつき電位) 付近の電流一電位 曲線を図 2 (b) に示す。腐食反応の場合, 総合反応の分極曲 線は測定できるが，同じ条件で局部カソード反応と局部ア ノード反応の分極曲線を分離して測定することはできない。 アルカリ性の無電解銅めっき反応では, 外部分極曲線はもち ろん局部アノードと局部カソード分極曲線を分離して測定す ることができ，このモデルの正当性が証明される。混成電位 論は他の無電解めっき反応にも普遍的に適用され, 反応機構 の解明に有力な手段となる。

\section{2. 各種無電解めっきの最近の動向}

\section{1 無電解ニッケルめっき}

無電解ニッケルめっきは, 用いる還元剤の種類によって $\mathrm{Ni}-\mathrm{P}$ (次亜リン酸塩), $\mathrm{Ni}-\mathrm{B}$ (ホウ素化合物), ほぼ純粋な $\mathrm{Ni}$ (ヒドラジン)の 3 種類がある。このうち実用化されているの は Ni-P が大部分で, Ni-B は特徴をいかして特殊な用途に 利用される。ヒドラジン浴は長い間実験室の段階に止まって
表 1 無電解 Ni-P めつきのリン含有率による分類と特徵

\begin{tabular}{lccc}
\hline & $\begin{array}{c}\text { 低リン } \\
\text { P 1-4\% }\end{array}$ & $\begin{array}{c}\text { 中リン } \\
\text { P 5-8\% }\end{array}$ & $\begin{array}{c}\text { 高リン } \\
\text { P 9-12\% }\end{array}$ \\
\hline 物理的性質 & & & \\
密度 $\mathrm{g} / \mathrm{cm}^{3}$ & 8.5 & 8.1 & 7.9 \\
軟化点 ${ }^{\circ} \mathrm{C}$ & 880 & 880 & 880 \\
電気抵抗 $\Omega \mathrm{cm}$ & $20-30$ & $50-60$ & $100+$ \\
熱伝導度 $\mathrm{cal} / \mathrm{cm} /{ }^{\circ} \mathrm{C}$ & 13 & 12 & 11 \\
機械的性質 & & & \\
抗張力 $\mathrm{MPa}$ & 200 & $300-900$ & $750-900$ \\
伸び率\% & $<0.5$ & 0.7 & $\sim 1.5$ \\
硬さ 未熱処理) $\mathrm{kg} / \mathrm{mm}^{2}$ & $650-700$ & $550-600$ & $500-550$ \\
テーバー摩耗 $\mathrm{TWI}$ & $10-12$ & $15-20$ & $20-25$ \\
鋼上応力 $\mathrm{kg} / \mathrm{mm}{ }^{2}$ & $10-20$ & \pm 5 & -5 \\
保磁力 $\mathrm{Oe}$ & 約 10 & $1-2$ & 0 \\
耐塩水噴霧時間 $\mathrm{h}$ & 24 & 200 & 1,000 \\
而酸性 & 不可 & 良 & 優 \\
はんだ付け性 & 秀 & 優 & 良 \\
構造 & 結晶性 & 中間 & 非晶質 \\
\hline
\end{tabular}

いたが，後述するように最近活発な研究が行われている。無 電解 Ni-P めつきは, 周知のようにBrenner の戦時研究に よって偶然に発明された。この技術は第 2 次大戦後米国の輸 送会社 GATX により Kanigen プロセスとして商品化され, 普及した。無電解 Ni-P めっきは耐摩耗性と耐食性にすぐれ る上に, 無電解めつきの最大の特徵である均一膜厚分布のた めに, OA 機器, 一般産業機械部品, 自動車部品, 電子部品 から宇宙航空機部品まで広く応用されている。

ことわりなしに無電解ニッケルといえば無電解 Ni-P めつ きのことをさすが，最近は同じ無電解 Ni-Pめつきでもリン 含有率によって低リン，中リン，高リンと差別してよばれる ようになった。以前から一般に使用されているのはリン 10\%弱の中リンタイプで, 外観やめっき速度の点で最も使 いやすい浴といえる。表 $1^{3)}$ は無電解 Ni-P めっきのリン含 有率とめっきの性質を示す一例である。この表で最も重要な ことは, リン含有率が高いほど非晶質性が増し，リン含有率 が低いほど結晶性が増すことである。非晶質な高リンめつき は耐食性にすぐれるが, 高リンめっきを得るためには低 $\mathrm{pH}$ 浴にする必要があり，そのためめつき速度は遅くなる。また， 非晶質性と非磁性は比例関係にあるので, 非磁性安定性を要 求されるハードディスク(アルミニウム素地)への下地無電解 ニッケルめっきには高リンタイプが使用される。硬さとリン 
含有率の関係については，めつきのまま(非熱処理)の硬さは 低リンの方が高いことが知られている。しかし，硬さと耐摩 耗性は必ずしも比例しない。Kreye ら ${ }^{4)}$ は Ni-P (2.3\%) と $\mathrm{Ni}-\mathrm{P}(10.0 \%)$ のつきの摩耗試験を行い, 低リンめつきの 摩耗量が明らかに小さいことを確認した。Zhang ら ${ }^{5)}$ は Ni $1.5 \% \mathrm{P}$ とi-10.5\%P を比較し, 前者は後者に対してはる かに高い硬さ, 弾性モジュラスおよび耐摩耗性を示すと報告 した。表 1 には見えないが，低りン浴は耐アルカリ性にすぐ れるという特徴をもっていて, Tracy ら ${ }^{6)}$ は, 苛性ソーダ移 送ポンプなど化学工場への無電解低リンめっきの応用例につ いて報告している。

標準的な工業用無電解 Ni-P めつきのめっき速度は約 20 $\mu \mathrm{m} / \mathrm{h}$ である。浴が老化するにつれてめつき速度は低下する。 Keping ら ${ }^{7)}$ は, 最高めつき速度をもつめつき浴組成を実験 により模索し， $32 \mu \mathrm{m} / \mathrm{h}$ のめつき速度をもつ浴組成を決定し た。この浴は安定剤としてフェニルチオ尿素を含み, 安定性 にもすぐれる。めっき浴の老化度は，めっき速度だけでなく めつきのリン含量や耐食性などについても影響する。Dun$\mathrm{kan}^{8)}$ は無電解 Ni-P めつきの耐食性に及ぼす浴老化度の影 響について調べた。めつき速度は新浴での $15 \mu \mathrm{m} / \mathrm{h}$ が 5 ターン後には $9 \mu \mathrm{m} / \mathrm{h}$ に低下した。めっきの老化にともなっ てめっきのリン含有率は増加した。このほか老化の進行に よって内部応力は引張り応力側に大きくなり，めっきの延性 と耐食性は明らかに低下した。無電解 Ni-P めつきの耐食性 はめっき膜の有孔度に明らかに関係すると思われる。 $\mathrm{Jin}^{91}$ らは, 浴に含む錯化剤が無電解 Ni-P めつきの有孔度と表面 形態に及ぼす影響について調べた。錯化剤としてはクエン酸 ソーダ，リンゴ酸および乳酸を用いて比較し, 有孔度の評価 には電気化学測定 (分極測定)を用いた。表面形態はAFM で 観察した。その結果, 有孔度の大きさの順位は乳酸>リンゴ 酸>クエン酸で,これは表面粗さの順位にも一致した。

無電解ニッケル浴に含まれるハロゲン類の影響についても 多くの研究がある。G-S Tzeng ${ }^{10)}$ は無電解 Ni-P めつきへの 浴中のハロゲンの影響について調べた。硫酸ニッケルと次亜 リン酸塩からなる基本浴に $\mathrm{NaF}, \mathrm{NaCl}, \mathrm{NaI}$ およひ $\mathrm{NaBr}$ をそれぞれ単独に加えて比較した。その結果, 各浴からの めっき速度の大きさの順位は, 浴 $\mathrm{A}$ (ハロゲン含まず)>浴 $\mathrm{B}(\mathrm{Cl})>$ 浴 $\mathrm{D}(\mathrm{Br})>$ 浴 $\mathrm{B}(\mathrm{F})>$ 浴 $\mathrm{E}(\mathrm{I})$ の順位であった。また, 同じ条件ではフッ素イオンを含む浴からのめつきのリン含有 率が最大であった。Keping ら ${ }^{11}$ は無電解ニッケルめつきへ のヨウ素イオンの影響について調べた。KI としてヨウ素イ オンを加えるとめつき速度が抑制され，浴が安定化される。 ヨウ素イオンの影響は部分アノード分極曲線に現れ, ヨウ素 イオンが次亜リン酸イオンの触媒サイトへのアクセスを妨害 すると考察した。Younan ら ${ }^{12)}$ は無電解 Ni-P めっきへの木 ウフッ化物イオンの影響について調べた。 $\mathrm{pH} 7$ の基本浴に ホウフッ酸としてホウフッ化物イオンを加えることにより, めっきのリン含有率が増加し, 最大 $810 \mathrm{VHN}$ の硬さが得ら れた。Martyak ${ }^{13)}$ は無電解ニッケル浴中のニッケル塩に三 フッ化メタンスルフォン酸塩を使用してめっきを行い, 硫酸 塩浴からのめつきに比べて高硬度が得られることを確認した。 また，浴が老化した時カルシウムを加えることによって亜り
ン酸塩のみが沈殿として除去され，ニッケル塩は沈殿しない ので，浴の再生が可能であると報告している。

無電解 Ni-B めっきは, SBH (Sodium Borohydride) また は DMAB (Dimethyl Amine Borane)を還元剤としてめっき され，0.3-3\%B を含むNi-Bめつきが得られる。初期に は SBH が使用されたが, $\mathrm{SBH}$ 浴は高温 $\left(90^{\circ} \mathrm{C}\right)$, 高 $\mathrm{pH}(>$ 13)を必要とする上に安定性に乏しい。これに対して DMAB 浴は弱酸性ないし中性浴も可能な上により低温 $\left(50-60^{\circ} \mathrm{C}\right)$ での操作が可能である。 $\mathrm{pH}$ などのめつき条件を 変えることによって B 含量を制御することもできる。無電 解 Ni-P に比較して Ni-B めっきは, (1)めっきのまま(未熱処 理)でより硬く, 耐摩耗性のめっきが得られる, (2)はんだ付 け性にすぐれる，(3)銅素材上に直接めっきができる，などの 特長がある。しかし, 次亜りン酸塩に比較して還元剤が格別 に高価なので, コストを考慮してもこれらの特長を活かした い電子部品など特殊な用途に限定される。このように用途が 限定されるためか, 無電解 Ni-P に比べて Ni-B の研究例は 少ない。高井ら ${ }^{14)}$ は DMABを還元剤とする無電解 Ni-B めつきによるマイクロパターニングにおける異常析出の抑制 について報告した。金ら ${ }^{15)}$ は無電解 Ni-B めつきにおける錯 化剈(クエン酸塩, マロン酸塩, グリシン, エチレントリア ミン)の析出速度, 皮膜組成, 皮膜構造への影響について調 べた。横島ら ${ }^{16)}$ は, 無電解 Ni-B めつきを用いたマイクロパ ターニングへの錯化刻の影響を調ベ, グリシン一硫酸アンモ ニウム混合錯塩浴のときにパターン通りの均一なめつき膜を 得た。金ら ${ }^{17)}$ は, 無電解 Ni-B めつき膜の結晶構造に及ぼす 共析元素 $(\mathrm{C}, \mathrm{B})$ の影響について報告した。

最近, わが国ではNi-B-Pめっき(低りン低ホウ素)が市販 されている。Ivanov ら ${ }^{18)}$ は硫酸ニッケル浴中に次亜りン酸 塩と SBH または DMAB を還元剤として用いて無電解 NiB-Pめっきを行った。物性の詳細には触れていないが, 安定 で十分高速度の良質なめっきが得られると報告した。 $\mathrm{Abd}$ ら ${ }^{19)}$ は次垔リン酸塩と SBH を還元剤として無電解 Ni-B-P めっきを行い, 反応速度論的な考察を行った。また本間ら 20) は, 電子回路の銅パターン上に触媒処理をせずに無電解ニッ ケルめっきをする手段として次亜リン酸塩浴に DMABを第 2 還元剂として用いる方法を試みた。無電解 Ni-P または $\mathrm{Ni}-\mathrm{B}$ に第三，第四の成分を加えた多元合金めっきの研究と しては，とくに磁気記録媒体としての CoNiReP に関する逢 坂らの業績 ${ }^{21)}$ がある。

ヒドラジンを還元剤とする無電解ニッケル浴からはほぼ純 粋なニッケルめつきが得られることが古くから知られている が, 実験室の段階を出ず, 浴安定性などに問題があった。田 代ら ${ }^{221}$ は, ヒドラジン一水和物を使用して安定性のよい浴 を模索した結果, 最適組成を確立した。この浴は浴安定性に すぐれ，めっき速度は約 $3 \mu \mathrm{m} / \mathrm{h}$ であった。得られためっき は黒色外観でほぼ純粋なニッケルであり，Ni-PやNi-B と 比較して電導性, はんだ濡れ性にすぐれており, 新用途の可 能性があると報告している。八重ら ${ }^{23), 24)}$ は, EDTA と乳酸 を用いるヒドラジン還元浴にサッカリンナトリウムやホルム アルデヒドを添加することにより, 光沢外観のニッケルめっ きを得た。 
無電解めつき浴の中に炭化ケイ素, アルミナ, ダイヤモン ドまたはPTFEなどの固形粒子を分散させてめっきするこ とを無電解複合めっきという。分散質によってさまざまな性 質が得られる。電気めつきと違って電流分布に影響されるこ となく均一な粒子分布の得られることが特徴である。無電解 PTFE 複合めつきの耐摩耗性については中尾の解説 ${ }^{25)}$ があ る。二硫化モリブデンは固体潤滑剤として知られているが, Moonir ら ${ }^{26)}$ は無電解 Ni-P 浴中に $\mathrm{MoS}_{2}$ を分散させて無電 解 Ni-P- $\mathrm{MoS}_{2}$ めっきを行い, 得られためっきの摩耗特性を 測定した。Feldstein ${ }^{27)}$ は, 分散粒子として発光性粒子を使 用することにより, UV 光を照射したときに発光する無電解 分散めつきについて解説している。この複合めつきは, 部品 の摩耗限界を知らせる指示用途とUV 光を当てることに よって本物を証明できる認証用途に応用することができる。 Xiang ら ${ }^{28)}$ は, ナノメータサイズの人工ダイヤモンドを分 散粒子とする無電解分散めっきについて報告している。

\section{2 無電解銅めつき}

実用されている無電解銅めっきの大部分はホルムアルデヒ ドを還元剤とする。後述するように, 非ホルムアルデヒド浴 もあるが, 物性やコストなどの総合面でホルムアルデヒド浴 には太刀打ちできない。ホルムアルデヒドは $37 \%$ 溶液(ホル マリン)または固形のパラホルムアルデヒドとして加えられ る。還元剤としてのホルムアルデヒドは $\mathrm{pH} 12$ 以上のアル カリ性で有効で, 酸性では働かない。一方, 第二銅イオンを アルカリ性溶液に維持するためには適切な錯化剤ないしキ レート剤が必要である。初期の一般用無電解銅めっき浴は ロッシェル塩(酒石酸カリウムナトリウム)を錯化剤として含 むアルカリ溶液に硫酸銅とホルムアルデヒドを加えたものを 基本浴とした。この浴に微量の安定剤を添加すると, 室温で 安定な操作が可能である。プラスチック表面またはプリント 配線板のスルーホール内の電導性付与にはこの種の室温操作 浴が使用できる。しかし, 得られるめつき膜は脆く, 厚付け には不向きである。その後, パターンめつきプロセス用の中 付け $(2-3 \mu \mathrm{m})$ やルアディティブ回路のための厚付け $(25 \mu \mathrm{m}$ 以上) 用の無電解銅めつきが要求されると, 電気銅 めっきなみの物性のよい無電解銅めっきを与える浴が必要に なった。その結果, EDTA やクオドロール $(\mathrm{N}, \mathrm{N}, \mathrm{N}$ ', N'テ トラキス(2-ヒドロキシプロピル)エチレンジアミン)のよう な高級キレート剤を使用する高温操作浴が開発された。これ らの浴からは, 電気銅めっきに匹敵する伸び率, 抗張力の めっきが得られる。電子回路に応用される無電解銅めっきの 進歩については Deckert ${ }^{29)}$ が展望している。

一方，ホルムアルデヒドは刺激臭のある人体に有害な化合 物で発癌物質として指定されているので，とくに欧州では規 制が㛜しく，ホルムアルデヒドを使用しない方法もしくは無 電解銅めっきそのものを省略して直接電気めっきする方法 (ダイレクトプレーティング)が開発された。非ホルムアルデ ヒド浴として, 無害無臭かつホルムアルデヒドと同等のめつ きを与える浴がグリオキシル酸浴で, 本間 ${ }^{30)}$, Darken $^{31)} ら$ の報告がある。

無電解ニッケルに使用される次亜りン酸塩の反応には銅は 触媒性をもたないので, 次亜リン酸塩を還元剤とする無電解
銅めっきは不可能とされていたが，めっき浴の主成分の銅塩 のほかに少量のニッケルを共存させることによって自己触媒 反応による連続的なめつきが可能になる ${ }^{32)}$ 。本間ら ${ }^{33), 34)}$ は この浴から特徵のある表面形態の銅めつき膜が得られること を利用して, 多層プリント配線板の内装銅箔の密着性改善の ための表面粗化に応用した。

Cheng ら ${ }^{35)}$ は次亜リン酸塩を還元剤とする無電解銅めつ きについて研究し, ホルムアルデヒド浴からのめつきに比べ てち密で平滑なめっきを得たと報告している。

最近 5 年間の無電解銅めつきの話題のハイライトといえば, Vaskelis ${ }^{36), 37)}$ による Co (II) を還元剂とする無電解銅めっき 浴の開発であろう。これはエチレンジアミン錯塩浴における $\mathrm{Co}^{2+} \rightarrow \mathrm{Co}^{3+}$ の酸化反応を駆動力とする無電解銅めっきで, 従来の還元剤のような水素発生をともなわない。ほぼ中性の 浴から $50-70^{\circ} \mathrm{C} て ゙ 6 \mu \mathrm{m} / \mathrm{h}$ 以上のめつき速度が報告されて いる。䋲舟ら ${ }^{38)}$ は, この浴の追試を行い, 水素の発生しな い無電解銅めっきが可能であることを確認した。無電解銅 めつきを含むめつき技術一般の先端電子回路への応用につい て本間らの解説 ${ }^{39)}$ がある。

\section{3 無電解貴金属めっき}

無電解金めっきには，置換反応によるものと自己触媒反応 によるものがある。置換型のめつきでは素材が金で被覆され ると反応は停止する。いいかえれば金の上に金めっきできな い。しかし還元剤を必要とせず, 操作が簡単なことや過剩 めっきの心配がいらないという長所もある。置換金めっき浴 については, Simonの解説 ${ }^{40)} や$ Keping らの研究報告 ${ }^{41)}$ が ある。置換型の無電解金めっきはプリント配線板のはんだ付 け性付与の目的で単独で用いられることもあるが, 一般に触 媒型無電解金めっき浴の污染防止のために，ストライクめっ きとして用いられる。触媒型の金めっきはシアン化金塩を用 い $\mathrm{KBH}_{4}$ または $\mathrm{DMAB}$ のうなホウ素化合物を還元剤と するいわばクラシックなシアン浴と, 非シアン金塩とホウ水 素化物以外の還元剤を用いる非シアン浴に分類される。シア ン浴は pH 13 以上の強アルカリ性で高温度で用いられる。 比較的安定で高めつき速度が得られるが耐アルカリ性に劣る 素材には不向きである。また, 電子回路用の無電解金めっき には，パターン形成のために有機レジストを用いることが多 い。これらのパターンめっきの場合にも, 高温高アルカリ性 のシアン浴では有機レジストが容易に侵されるので, シアン 浴を使用することはできない。

Sullivan $ら^{42)}$ は, 中性溶液で操作可能な無電解金めっき を求めて, 金塩としてのチオ硫酸金と各種還元剤 (ホウ水素 化物, 次亜リン酸塩, ヒドロキシルアミン, ヒドラジン, ア スコルビン酸)の組合せについて pH 7.2 と $\mathrm{pH} 9.2$ で混成電 位論に基づく電気化学測定を行い, アスコルビン酸が最も有 望であると結論した。これに基づいて室温, $\mathrm{pH} 6.4$ の最適 組成を確立した。さらに, この研究を延長して, アスコルビ ン酸浴に過酸化水素を添加することによって, 老化によるチ 才硫酸塩の蓄積を防ぐことができると報告した ${ }^{43)}$ 。加藤ら ${ }^{44)}$ は, 金塩として亜硫酸一チオ硫酸混合塩を用い, アスコルビ ン酸を還元剤とする浴について詳しい研究を行った。井上 ら ${ }^{45), 46)}$ は, 金塩としてジチオ硫酸金を用い, チ才尿素を還 
元剂とする非シアン無電解金めつき浴について研究し, $\mathrm{pH}$ 8 , 温度 $70^{\circ} \mathrm{C}$ で操作する基本浴にハイドロキノンを加えた 高安定性の最適組成を確立した。

Iacovangelo ら ${ }^{47)}$ は, 素材触媒型無電解金めっきシステ ムを開発した。この浴はヒドラジンを還元剤とするもので, ニッケル下地めっき上に適用するとき，七ドラジンはニッケ ルを触媒として反応するがニッケルが金めつきで完全に被覆 されると反応は自動停止する。このタイプの金めつきは従来 の置換型めつき特有の素材の溶解がなく, 薄膜でもち密な金 めつきができる。逢坂ら ${ }^{48)}$ は, 無電解 Ni-B と Ni-P 上にヒ ドラジンを還元剤とする素材触媒型無電解金めっきを行い, 得られる金めつきは素材表面の性質に依存し, Ni-B または 酸化膜のない $\mathrm{Ni}$ - $\mathrm{P}$ 上に満足な金めっきが得られると報告し た。加藤 ${ }^{49}$ は, 素材触媒型無電解金めっきのその後の進歩 について解説している。

無電解銀めつきの方法は古くから銀鏡反応が知られている が,この方法では厚付けが不可能である。シアン化銀錯塩溶 液から DMAB を還元剤とする自己触媒浴が報告されてい

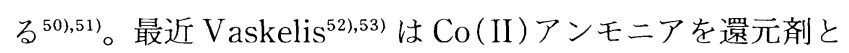
する無電解銀めっきについて報告した。アンモニア溶液から $\mathrm{Co}$ (II) を還元剤とし, $\mathrm{pH} 8.5-9.5,50^{\circ} \mathrm{C}$ で 3 時間に $7 \mu \mathrm{m}$ の光沢銀めっきが得られたと報告している。縄舟ら ${ }^{54)}$ は2-ア ミノエタンチオールを還元剤とする無電解銀めっきについて 研究し, 中性浴からの自己触媒型の無電解銀めつきが可能で あることを確認した。

(2001-9-26 受理)

\section{文献}

1) 斎藤 囲; 金属表面技術, 16, 300 (1965)，17，14，17，258，

17, 264 (1966)

2) M. Paunovic ; Plating, 55(11), 1161 (1968)

3 ) Konrad Parker ; Plating \& Surf. Fin., 79, No. 3 (1992)

4) H. Kreye; Metalloberflache, 47, No. 8 (1993)

5 ) Y.Z.Zhang; Trans. IMF, 77, No. 2, 833 (1999)

$6)$ R. P. Tracy, R. E. Miller ; Corrosion, April, 17 (1989)

7) Han Keping et al. ; Trans. IMF, 69, No. 3, 91 (1991)

$8)$ R. N. Dunkan ; Plating \& Surf. Fin., 83, No. 10 (1996)

9) Yun Jin et al. ; Trans. IMF, 77, No. 5, 181 (1999)

10) G-S Tzeng ; J. Applied Electrochem., 26, 1969 (1996)

11) Han Keping, Fang Jingli ; Trans. IMF, 74, No. 3 (1996)

12) M. M. Younan et al. ; Galvonotechnik, 92, No. 6 (2001)

13) N. M. Martyak ; Trans. IMF, 79, No. 4, 129 (2001)

14）高井まどか, 竹房さなえ, 横島時彦, 逢坂哲彌; 表面技術, 48, 98 (1997)

15）金 満, 東川太一, 飯塚 淳, 逢坂哲彌; 表面技術, 48, 1099
(1997)

16）横島時彦, 湯浅寛子, 金 満, 逢坂哲彌 ; 表面技術, 49, 1336 (1998)

17）金 満, 飯塚 淳, 久保宮敬幸, 逢坂哲彌；表面技術, 50, 353 (1999)

18) M. V. Ivanov et al. ; Zaschita Metallov, 35, 375 (1999)

19) S. S. Abd et al. ; Plating \& Surf. Fin., 86, 94 (1999)

20）田代雄彦, 橋本幸雄, 本間英夫 ; 表面技術, 52, 289 （2001）

21）逢坂哲彌；表面技術, 44, 767 （1993）

22）田代雄彦, 渡辺大樹, 稲葉裕之, 本間英夫 ; 表面技術, 51, 606 (2000)

23）八重真治, 伊藤 潔, 山岸憲史, 松田 均; 表面技術, 51, 99 (2000)

24）八重真治, 中野久雄, 伊藤 潔, 山岸憲史, 松田 均; 表面技術, 51, 1035 (2000)

25）中尾英弘；表面技術，51，1085（2000）

26) S. M. Moonir, A. Saatchi ; Metal Fin., 95, No. 11 (1997)

27) M. D. Feldstein ; Metal Fin., 97, No. 2, 87 (1999)

28) Y. Xiang et al. ; Plating \& Surf. Fin., 88, 64 (2001)

29) C. A. Deckert ; Plating \& Surf. Fin., 82, No. 2, 3 (1995)

30）本間英夫, 小松素明, 藤波知之 ; 表面技術, 42, 913 （1991）

31) J. Danken ; Trans. IMF, 69, No. 2 (1992)

32) A. Hung, I. Ohno ; Plating \& Surf. Fin., 77, No. 1 (1988)

33）藤波知之, 本間英夫：プリント回路学会講演大会論文集, p.109 (1990)

34）水口 泰, 小林 健, 藤波知之, 本間英夫 ; 表面技術, 49, 1327 (1998)

35) D. H. Cheng et al. ; Metal Finishing, 95, No. 1 (1997)

36) A. Vaskelis et al. ; Trans. IMF, 75, No. 1 (1997)

37) A. Vaskelis et al.; Galvanotechnik, 90, No.6 (1997)

38）縄舟秀美, 内尾誠一郎, 水本省三, 村上義樹, 松本 伸; 表面技 術, 49, 1360 (1998)

39）三浦修平, 本間英夫；表面技術, 52, 366 （2001）

40) F. Simon; Galvanotechnik, 83, No. 11 (1992)

41) H. Keping, F. Jingli ; Trans. IMF, 74, No. 3 (1996)

42) A. M. Sullivan ; Proceedings SUR/FIN'94, p.594 (1994)

43) A. M. Sullivan ; J. Electrochem. Soc., 142, No. 7 (1995)

44) M. Kato et al. ; Proceedings SUR/FIN'95, p.805, (1995)

45) T. Inoue et al. ; IEEE 0569-5503/95/0000-1059 (1995)

46）井上隆史, 安藤節夫, 牛尾二郎, 奥平弘明, 竹原裕子, 大田敏彦,

山本 弘, 横野 中；表面技術, 49, 1298 (1998)

47) C. D. Ianovangelo ; J. Electrochem. Soc., 138, No. 4 (1991)

48) T. Osaka et al ; J. Electrochem. Soc., 147, 1059 (200)

49）加藤 勝；表面技術協会めっき部会 6 月例会資料（2001）

50) A. F. Bogenschutz ; Galvanotechnik, 82, No. 2 (1991)

51) A. F. Bogenschutz ; Galvanotechnik, 82, No. 3 (1991)

52) A. Vaskelis et al. ; Galvanotechnik, 91, No. 8 (2000)

54）縄舟秀美, 城口慶子, 谷久保正人, 水本省三, 小橋康人, 竹内孝 夫；表面技術, 50, 928 (2000) 